\title{
ANALISIS PENERAPAN SISTEM INFORMASI AKADEMIK (SIAKAD) 2013 MENGGUNAKAN MODEL END-USER COMPUTING SATISFACTION (EUCS) DI PROGRAM STUDI PENDIDIKAN TEKNIK INFORMATIKA
}

\author{
Handaru Jati, Ratna Wardani, Nur Hasanah, Ahmad Awaluddin Baiti, Bonita Destiana \\ Prodi Pendidikan Teknik Informatika, Jurusan Pendidikan Teknik Elektronika FT UNY \\ Email: handaru@uny.ac.id
}

\begin{abstract}
ABSTRAK
Penelitian ini bertujuan untuk mengetahui: (1) pengaruh content terhadap user satisfaction; (2) pengaruh accuracy terhadap user satisfaction; (3) pengaruh format terhadap user satisfaction; (4) pengaruh ease of use terhadap user satisfaction; (5) pengaruh timeliness terhadap user satisfaction. Penelitian ini merupakan penelitian ex-post facto, yang dilaksanakan di Program Studi Pendidikan Teknik Informatika. Teknik pengambilan sampel dengan purposive sampling. Sampel yang diambil merupakan mahasiswa angkatan 2013 dan 2014 yang sudah menggunakan SIAKAD 2013. Data diperoleh dengan kuesioner tertutup yang telah memenuhi persyaratan validitas dan reliabilitas. Teknik analisis data yang digunakan adalah Partial Least Square (PLS). Hasil penelitian menunjukkan bahwa: (1) content berpengaruh terhadap user satisfaction; (2) accuracy berpengaruh terhadap user satisfaction; (3) format berpengaruh terhadap user satisfaction; (4) ease of use berpengaruh terhadap user satisfaction; (5) timeliness berpengaruh terhadap user satisfaction.
\end{abstract}

Kata Kunci: sistem informasi, analisis kepuasan, EUCS

\section{PENDAHULUAN}

Teknologi informasi merupakan salah satu unsur yang berperan penting dalam perkembangan jaman pada saat ini, terutama bagi sebuah organisasi atau institusi. Teknologi informasi merupakan suatu perangkat yang berbasis komputer yang digunakan untuk mengolah dan memproses data menjadi informasi yang berkualitas yang diperlukan sesuai kebutuhan atau tujuan. Oleh karena itu, teknologi informasi dapat memudahkan pengelola organisasi atau institusi sehingga setiap kegiatan administrasi dan manajemen dapat dikontrol dengan baik. Namun, kemudahan kontrol yang ditawarkan teknologi informasi tersebut hanya dapat dimanfaatkan oleh pihak internal organisasi atau institusi. Oleh karena itu diperlukan tambahan teknologi sehingga dapat membuat kinerja sebuah organisasi lebih berkembang, teknologi yang diperlukan tersebut adalah teknologi komunikasi.

Penggabungan teknologi informasi dan teknologi komunikasi dikenal dengan teknologi infomasi dan komunikasi (TIK). TIK adalah segala cara atau alat yang terintegrasi sehingga dapat digunakan untuk menjaring, mengolah dan menyajikan data secara elektronik menjadi informasi dalam berbagai format yang bermanfaat bagi pengguna serta memungkinkan pengguna untuk menerima informasi atau bertukar informasi serta berkomunikasi dengan pihak lain. Penggunaan teknologi informasi dan komunikasi dapat membuat kinerja organisasi lebih efektif, efisien dan kompetitif (Akadun, 2009: 1-2). Salah satu contoh organisasi yang sudah terbiasa dengan penggunaan TIK adalah perguruan tinggi (universitas).

Universitas Negeri Yogyakarta (UNY) merupakan salah satu universitas yang 
peduli terhadap manajemen informasi akademik. Hal ini terbukti dari terus dikembangkannya sistem informasi akademik (Siakad) guna melayani semua kegiatan akademik anatara dosen dan mahasiswa. UPT yang diserahi tugas untuk mengelola siakad tersebut adalah Pusat Komputer (PUSKOM) UNY. Sampai saat ini, UNY telah melakukan dua kali pengembangan siakad. Siakad pertama yang beralamatkan di siakad.uny.ac.id sudah tidak difungsikan lagi dan digantikan dengan siakad2013.uny.ac.id. Penggantian sistem ini dimaksudkan untuk memperbaiki dan melengkapi kekurangan-kekurangan yang ada pada siakad yang lama.

Salah satu contoh perubahan pada siakad baru atau Siakad 2013 dapat langsung dilihat dari segi tampilan yang menjadi responsive atau dapat menyesuaikan dengan berbagai jenis ukuran atau resolusi layar perangkat (gadget). Namun, dalam proses peremajaan siakad ini belum dilakukan pengkajian lebih lanjut mengenai penerapan sistem berdasarkan persepsi pengguna (user).

Pada penelitian ini selanjutnya akan dikaji lebih lanjut mengenai faktor-faktor yang mempengaruhi user dalam menggunakan Siakad 2013. Penelitian mengenai faktor-faktor yang berpengaruh terhadap user dalam penerapan suatu sistem sangatlah penting karena konsep-konsep utama dalam pengembangan teknologi informasi meliputi user, hardware, software, jaringan, manajemen, dan teknologi berbasis internet.

User atau sumber daya manusia dibutuhkan untuk pengoperasian teknologi informasi. Menurut Bodnar dan Hopwood (2012: 24) pengguna teknologi adalah manusia yang secara psikologi memiliki suatu perilaku (behavior) tertentu yang melekat pada dirinya, sehingga aspek keperilakuan dalam konteks manusia sebagai pengguna (user) menjadi penting sebagai faktor penentu keberhasilan pemanfaatan teknologi.

Jogiyanto (2008: 255) juga menyatakan bahwa merupakan hal yang penting untuk mengetahui faktor-faktor apa saja yang mempengaruhi individu pengguna (user) dalam adopsi suatu teknologi. Teori yang mendukung pernyataan tersebut adalah teori tindakan beralasan (theory reasoned action) oleh Fishbein dan Ajzen (1975: 30). Teori tersebut menyatakan bahwa pengguna (user) yang mendapatkan manfaat (outcomes) positif maka akan terus menggunakan atau memanfaatkan teknologi tersebut.

Salah satu model yang dapat digunakan untuk mengukur kepuasan user terhadap penerapan suatu sistem informasi adalah model End-User Computing Satisfaction (EUCS). Model ini dikembangkan oleh Doll dan Torkzades (1988). Pada model EUCS terdapat lima faktor yang dapat mempengaruhi kepuasan user terhadap penerapan suatu sistem informasi (Doll \& Torkzadeh, 1988: 259). Faktor-faktor tersebut adalah: isi (Content), ketepatan (Accuracy), bentuk (Format), kemudahan penggunaan (Ease of Use), dan ketepatan waktu (Timeliness).

Penelitian-penelitian sebelumnya menunjukkan bahwa kegagalan dari penerapan suatu sistem informasi terutama berkaitan dengan masalah perilaku pengguna (user behavioral issues) daripada masalah teknis (technical issues). Masalah perilaku pengguna harus ditangani dalam analisis pihak pengembang (stakeholder), khususnya pada tahap analisis kebutuhan 
sistem. Untuk itu, analisis pengguna akhir (end-user analysis) adalah salah satu fokus yang harus diperhatikan dalam analisis pengembang sistem. Namun, pada penerapan suatu sistem informasi terkadang pengembang tidak melaksanakan analisis kebutuhan sistem sesuai pengguna, sehingga pada saat penerapan sistem tersebut tidak dapat memenuhi kebutuhan pengguna.

Analisis pengguna juga diperlukan pada saat penerapan sistem tidak hanya pada tahap pengembangan. Hal ini dikarenakan, tingkat kepuasan pengguna akhir (end user satisfaction) yang diukur akan dapat berpengaruh terhadap kesuksesan penerapan sistem informasi. Namun, saat sistem informasi sudah diterapkan biasanya pihak pengembang lantas melepaskan sistem tanpa melakukan analisis lebih lanjut mengenai tingkat kepuasan pengguna akhir terhadap kinerja sistem tersebut.

Berdasarkan uraian di atas, penelitian ini akan menguji pengaruh faktor-faktor EUCS terhadap kepuasan mahasiswa Program Studi Pendidikan Teknik Informatika dalam menggunakan Siakad 2013.

\section{METODE}

Jenis penelitian yang digunakan pada penelitian kali ini adalah penelitian ex post facto. Penelitian ex post facto merupakan suatu penelitian yang dilakukan untuk meneliti peristiwa yang telah terjadi dan kemudian merunut ke belakang untuk mengetahui fakto-faktor yang menyebabkan timbulnya kejadian tersebut. Pendekatan yang digunakan dalam penelitian ini adalah pendekatan kuantitatif. Menurut Suharsimi Arikunto (2006: 12), penelitian kuantitatif adalah pendekatan penelitian yang menggunakan angka mulai dari pengumpulan data, penafsiran terhadap data tersebut, serta penampilan hasilnya.

Subjek dalam penelitian ini adalah mahasiswa Program Studi Pendidikan Teknik Infomatika, Jurusan Pendidikan Teknik Elektronika, Fakultas Teknik UNY. Cara pengambilan sampel dengan menggunakan teknik purposive sampling yaitu teknik penentuan sampel berdasarkan pertimbangan tertentu yaitu berdasarkan tujuan penelitian. Berdasarkan tujuan penelitian maka sampel penelitian yang diambil adalah mahasiswa Program Studi Pendidikan Teknik Infomatika angkatan 2013 dan 2014. Pengambilan tahun angkatan ini didasarkan pada tahun diterapkannya SIAKAD 2013 di UNY.

Tabel 1. Populasi dan Sampel Proporsional Tiap Angkatan

\begin{tabular}{ccc}
\hline No & Angkatan Mahasiswa & Jumlah \\
\hline 1 & Program Studi PTI 2013 & 114 \\
\hline 2 & Program Studi PTI 2014 & 70 \\
\hline & Total & 184 \\
\hline
\end{tabular}

\section{HASIL DAN PEMBAHASAN}

\section{Analisis Data}

\section{a. Perancangan inner model}

Perancangan inner model hubungan antar konstruk didasarkan pada rumusan masalah atau hipotesis penelitian. Berikut perancangan inner model dengan menggunakan software smartPLS: 


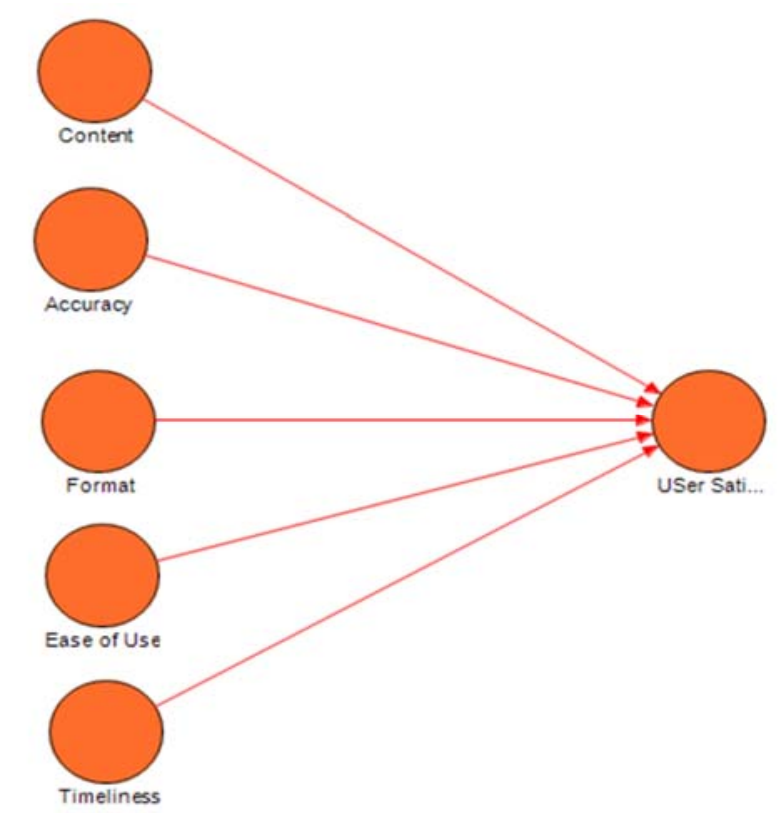

Gambar1. Perancangan Inner Model

\section{b. Perancangan outer model}

Sifat indikator dari masing-masing konstruk baik pada konstruk Content, Accuracy, Format, Ease of Use, Timeliness, dan User Satisfaction pada outer model adalah refleksif. Sehingga arah panah pada model pengukuran dari arah konstruk menuju indikator.

Perancangan outer model dengan menggunakan software smartPLS sebagai berikut:

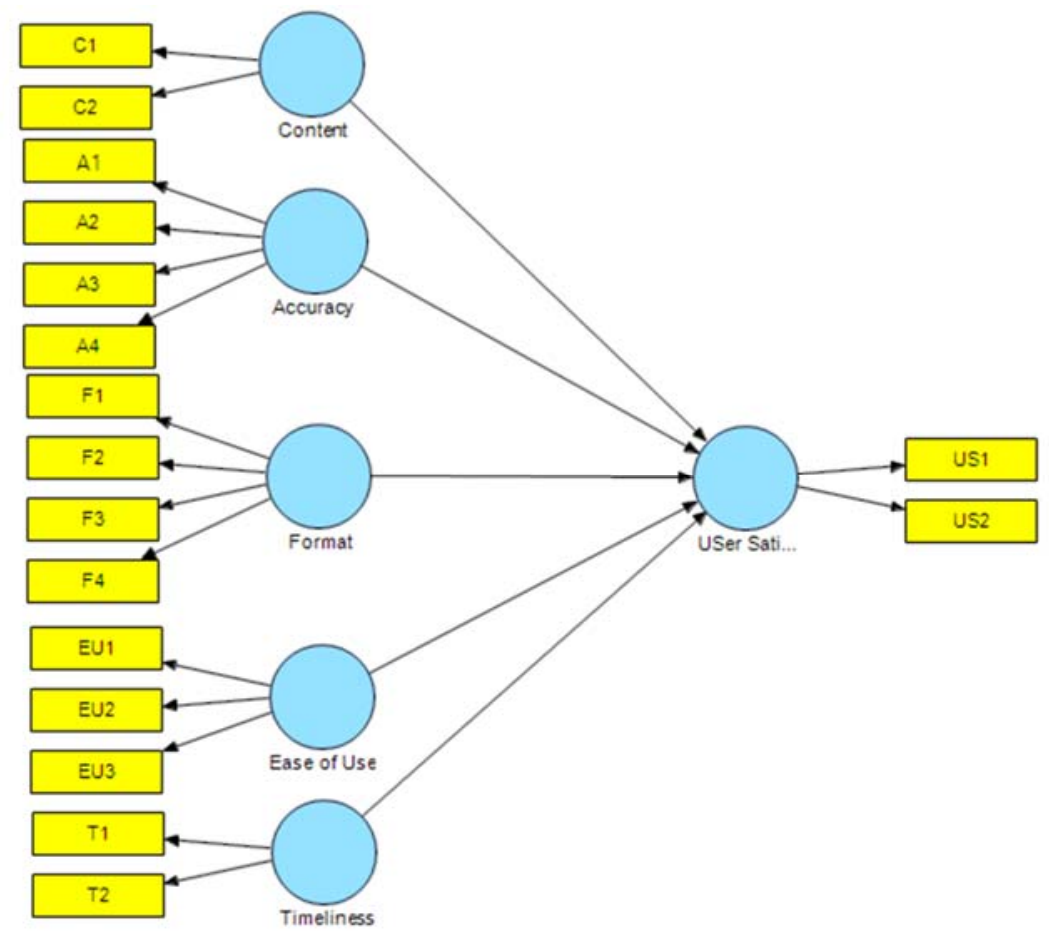

Gambar 2. Perancangan Outer Model 


\section{c. Estimasi model}

Metode pendugaan parameter (estimasi) di dalam penelitian ini menggunakan PLS Algorithm pada software smartPLS. Ketentuan untuk menguji unidimensionalitas dari setiap konstruk dengan melihat convergent validity.
Kriteria ukuran refleksif individual dikatakan tinggi jika berkorelasi lebih dari 0,70 dengan konstruk yang diukur. Namun, loading faktor 0,50 sampai 0,60 masih dapat dipertahankan untuk model tahap pengembangan (Chin, 1998).

Hasil eksekusi model dengan PLS Algorithm sebagai berikut

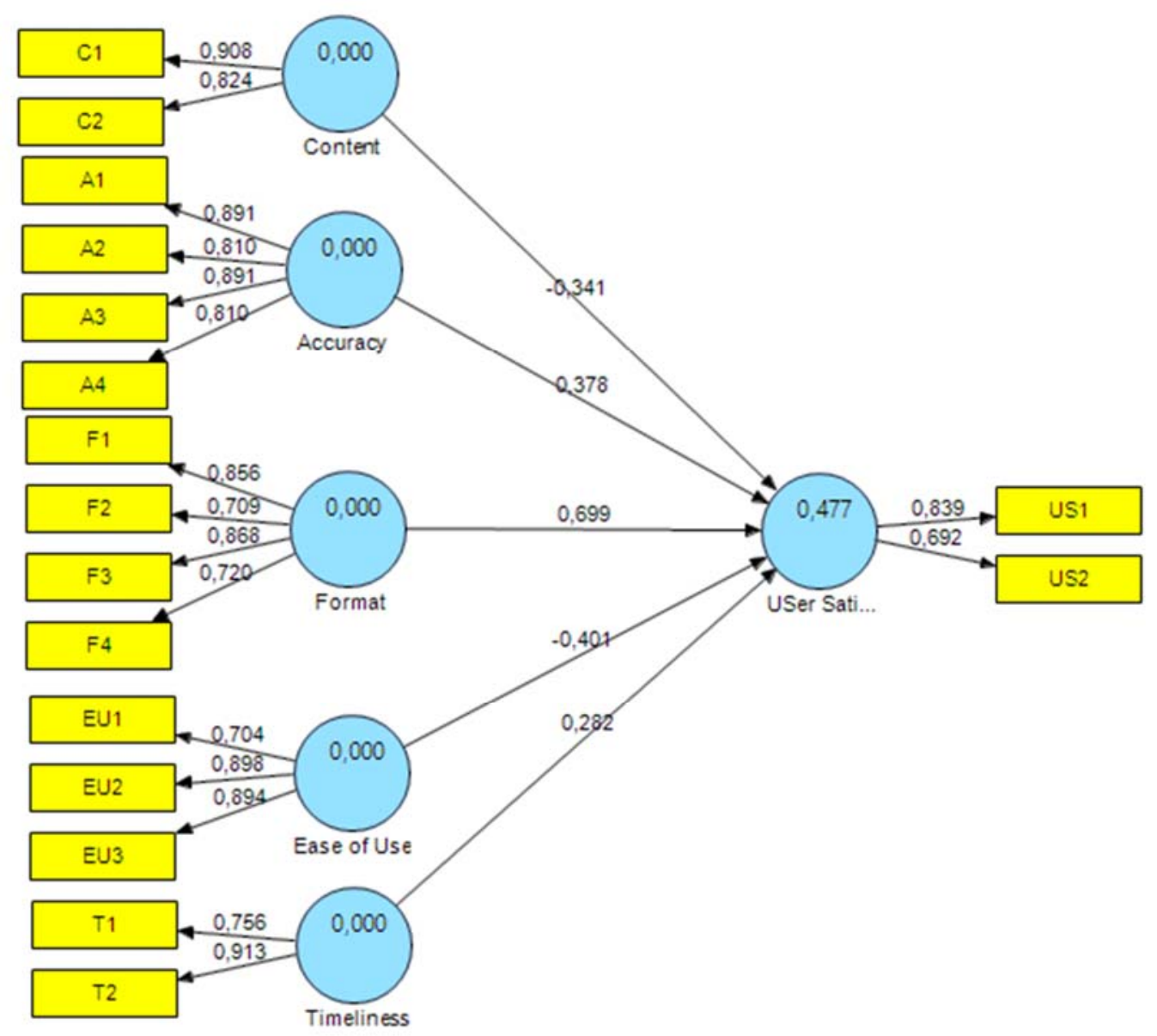

Gambar 3. Loading Factor Eksekusi Model Pertama

Gambar 3 menunjukkan bahwa sudah tidak ada indikator dari model yang memiliki loading faktor di bawah 0,50 sehingga model selanjutnya dapat dievaluasi.

\section{d. Evaluasi model}

Evaluasi model untuk outer model dan inner model selanjutnya dilakukan dengan membaca hasil report dari PLS Algorithm.
Pengujian outer model untuk mengevaluasi outer model dengan indikator refleksif terdapat 3 kriteria yaitu convergent validity, discriminant validity dan composite reliability.

Convergent validity dari measurement model dengan indikator refleksif dapat dilihat dari korelasi antara score item/indikator dengan konstruksnya 
(loading factor) yang dapat dilihat dari output outer loading. Output outer loading hasil estimasi kedua dari PLS Algorithm sebagai berikut

Tabel 2. Output Outer Loading

\begin{tabular}{|l|l|l|l|l|l|l|}
\hline & Accuracy & Content & $\begin{array}{c}\text { Ease of } \\
\text { Use }\end{array}$ & Format & Timeliness & $\begin{array}{c}\text { User } \\
\text { Satisfaction }\end{array}$ \\
\hline A1 & 0,891137 & & & & & \\
\hline A2 & 0,809811 & & & & & \\
\hline A3 & 0,890923 & & & & & \\
\hline A4 & 0,810279 & & & & & \\
\hline C1 & & 0,908084 & & & & \\
\hline C2 & & 0,824214 & & & & \\
\hline EU1 & & & 0,704204 & & & \\
\hline EU2 & & & 0,897727 & & & \\
\hline EU3 & & & 0,894305 & & & \\
\hline F1 & & & & 0,856129 & & \\
\hline F2 & & & & 0,709429 & & \\
\hline F3 & & & & 0,868093 & & \\
\hline F4 & & & & 0,720323 & & \\
\hline T1 & & & & & 0,755634 & \\
\hline T2 & & & & & 0,912752 & \\
\hline US1 & & & & & & \\
\hline US2 & & & & & & \\
\hline
\end{tabular}

Berdasarkan pada output outer loading dapat dilihat bahwa hasil loading factor semua indikator untuk masing-masing konstruk sudah memenuhi convergent validity, karena semua nilai loading factor setiap indikator sudah di atas 0,50 .
Discriminant validity dari indikator refleksif dapat dilihat pada cross loading antara indikator dengan konstruknya. Output cross loading hasil output PLS Algorithm sebagai berikut : 
Tabel 3. Output Cross Loading

\begin{tabular}{|c|c|c|c|c|c|c|}
\hline & Accuracy & Content & Ease of Use & Format & Timeliness & $\begin{array}{c}\text { User } \\
\text { Satisfaction }\end{array}$ \\
\hline A1 & $\mathbf{0 , 8 9 1 1 3 7}$ & 0,835921 & 0,486100 & 0,866456 & 0,439876 & 0,616893 \\
\hline A2 & $\mathbf{0 , 8 0 9 8 1 1}$ & 0,484187 & 0,801335 & 0,720323 & 0,800191 & 0,489551 \\
\hline A3 & $\mathbf{0 , 8 9 0 9 2 3}$ & 0,837454 & 0,491543 & 0,868093 & 0,450455 & 0,619115 \\
\hline A4 & $\mathbf{0 , 8 1 0 2 7 9}$ & 0,488078 & 0,806676 & 0,715980 & 0,809146 & 0,481494 \\
\hline C1 & 0,693198 & $\mathbf{0 , 9 0 8 0 8 4}$ & 0,494154 & 0,856129 & 0,404444 & 0,485890 \\
\hline C2 & 0,699865 & $\mathbf{0 , 8 2 4 2 1 4}$ & 0,461608 & 0,672585 & 0,413090 & 0,359336 \\
\hline EU1 & 0,425925 & 0,445945 & $\mathbf{0 , 7 0 4 2 0 4}$ & 0,573777 & 0,479418 & 0,329119 \\
\hline EU2 & 0,795523 & 0,501952 & $\mathbf{0 , 8 9 7 7 2 7}$ & 0,713964 & 0,863767 & 0,493148 \\
\hline EU3 & 0,673286 & 0,431236 & $\mathbf{0 , 8 9 4 3 0 5}$ & 0,624707 & 0,788390 & 0,375771 \\
\hline F1 & 0,693198 & 0,808084 & 0,494154 & $\mathbf{0 , 8 5 6 1 2 9}$ & 0,404444 & 0,485890 \\
\hline F2 & 0,502164 & 0,547389 & 0,602742 & $\mathbf{0 , 7 0 9 4 2 9}$ & 0,520179 & 0,373718 \\
\hline F3 & 0,800923 & 0,837454 & 0,491543 & $\mathbf{0 , 8 6 8 0 9 3}$ & 0,450455 & 0,619115 \\
\hline F4 & 0,709811 & 0,484187 & 0,691335 & $\mathbf{0 , 7 2 0 3 2 3}$ & 0,640191 & 0,489551 \\
\hline T1 & 0,308211 & 0,194368 & 0,499867 & 0,358192 & $\mathbf{0 , 7 5 5 6 3 4}$ & 0,328813 \\
\hline T2 & 0,812431 & 0,526222 & 0,893498 & 0,728932 & $\mathbf{0 , 9 1 2 7 5 2}$ & 0,527204 \\
\hline US1 & 0,546432 & 0,463211 & 0,286708 & 0,556292 & 0,323706 & $\mathbf{0 , 8 3 9 4 5 7}$ \\
\hline US2 & 0,456300 & 0,279401 & 0,500132 & 0,409377 & 0,525976 & $\mathbf{0 , 6 9 1 5 0 4}$ \\
\hline
\end{tabular}

Berdasarkan tabel output cross loading dapat dilihat bahwa korelasi masingmasing indikator dengan konstruknya lebih tinggi daripada dengan konstruk lain. Hal ini menunjukan bahwa konstruk laten memprediksi indikator pada bloknya sendiri lebih baik dibandingkan dengan indikator di blok lain.

Metode lain untuk menilai discriminant validity adalah dengan membandingkan nilai akar kuadrat dari $A V E$ $(\sqrt{A V E})$ setiap konstruk dengan nilai korelasi antara konstruk dengan konstruk lainnya (latent variable correlation).

Model memiliki nilai discriminant validity yang cukup apabila nilai akar AVE untuk setiap konstruk lebih tinggi daripada nilai latent variable correlation. Output AVE dan latent variable correlation dari PLS Algoritm sebagai berikut : 
Tabel 4. Output AVE dan Akar AVE

\begin{tabular}{|c|c|c|}
\hline & AVE & Akar AVE \\
\hline Accuracy & 0,725054 & 0,851501028 \\
\hline Content & 0,751973 & 0,867163768 \\
\hline Ease of Use & 0,700533 & 0,836978494 \\
\hline Format & 0,627175 & 0,791943811 \\
\hline Timeliness & 0,702049 & 0,837883643 \\
\hline $\begin{array}{c}\text { User } \\
\text { Satisfaction }\end{array}$ & 0,591433 & 0,769046813 \\
\hline \multicolumn{2}{|c|}{} \\
\hline
\end{tabular}

AVE setiap konstruk lebih tinggi dibandingkan dengan nilai korelasi setiap konstruk terhadap konstruk lainnya. Sebagai contoh nilai akar AVE dari konstruk Accuracy sebesar 0,8515 lebih tinggi dari nilai korelasi Accuracy dengan Content sebesar 0,7978, lebih tinggi dari nilai korelasi Accuracy dengan Format sebesar 0,7372 dan seterusnya. Jadi dapat disimpulkan bahwa semua konstruk dalam model yang diestimasi memenuhi kriteria discriminant validity.

Berdasarkan perbandingan Tabel 4 dan Tabel 5 dapat dilihat bahwa nilai akar

Tabel 5. Output Latent Variable Correlation

\begin{tabular}{|c|c|c|c|c|c|c|}
\hline & Accuracy & Content & $\begin{array}{c}\text { Ease of } \\
\text { Use }\end{array}$ & Format & Timeliness & $\begin{array}{c}\text { User } \\
\text { Satisfaction }\end{array}$ \\
\hline Accuracy & 1,000000 & & & & & \\
\hline Content & 0,797811 & 1,000000 & & & & \\
\hline Ease of Use & 0,777304 & 0,550552 & 1,000000 & & & \\
\hline Format & 0,737193 & 0,691876 & 0,767592 & 1,000000 & & \\
\hline Timeliness & 0,725892 & 0,467797 & 0,770832 & 0,688086 & 1,000000 & \\
\hline $\begin{array}{c}\text { User } \\
\text { Satisfaction }\end{array}$ & 0,654352 & 0,495270 & 0,487582 & 0,635642 & 0,529093 & 1,000000 \\
\hline
\end{tabular}

Selain uji validitas konstruk, dilakukan juga uji reliabilitas konstruk yang diukur dengan dua kriteria yaitu composite reliability dan croncbach alpha dari blok indikator yang mengukur konstruk. Konstruk dinyatakan reliabel jika nilai composite reliability di atas 0,70 (Ghozali, 2006). Output composite reliability pada Tabel 6.

\begin{tabular}{|c|c|}
\hline & Composite Reliability \\
\hline Accuracy & 0,913228 \\
\hline Content & 0,858145 \\
\hline Ease of Use & 0,873990 \\
\hline Format & 0,869628 \\
\hline Timeliness & 0,823667 \\
\hline User Satisfaction & 0,741493 \\
\hline \hline
\end{tabular}

Tabel 6. Output Composite Reliability 
Output composite reliability di Tabel 6 menunjukkan bahwa nilai masing-masing konstruk sudah di atas 0,70 . Sehingga dapat disimpulkan bahwa masing-masing konstruk dalam model yang diestimasi memiliki reliabilitas yang baik.

Setelah model yang diestimasi memenuhi kriteria discriminant validity. Selanjutnya dilakukan pengujian terhadap model struktural (inner model) yang dilakukan dengan melihat nilai R-square $\left(R^{2}\right)$ pada konstruk endogen.

Model struktural yang memiliki hasil $\begin{array}{lll}\mathrm{R} \text {-square } & \left(R^{2}\right) \quad \text { sebesar } & 0.67\end{array}$ mengindikasikan bahwa model "baik", Rsquare $\left(R^{2}\right)$ sebesar 0.33 mengindikasikan bahwa model "moderat", dan R-square $\left(R^{2}\right)$ sebesar 0.19 mengindikasikan bahwa model "lemah" (Ghozali, 2006). Nilai R-square $\left(R^{2}\right)$ konstruk endogen dari estimasi model sebagai berikut:

Tabel 7. Output R-square $\left(R^{2}\right)$

\begin{tabular}{|c|c|}
\hline & R Square \\
\hline Accuracy & \\
\hline Content & \\
\hline Ease of Use & \\
\hline Format & \\
\hline Timeliness & \\
\hline User Satisfaction & 0,476697 \\
\hline
\end{tabular}

Berdasarkan kriteria model, ketiga nilai R-square $\left(R^{2}\right)$ pada tabel di atas mengindikasikan bahwa model struktural (inner model) pada penelitian ini termasuk kategori model "moderat".

Nilai R-square $\left(R^{2}\right)$ konstruk endogen User Satisfaction pada model diperoleh sebesar 0,48. Hal ini berarti bahwa konstrukkonstruk eksogen pada model hanya dapat menjelaskan konstruk User Satisfaction sebesar $48 \%$ dan sisanya dijelaskan oleh variabel lain di luar model.

\section{e. Pengujian hipotesis}

Pengujian hipotesis antar konstruk yaitu konstruk eksogen terhadap konstruk endogen $(\gamma)$ dan konstruk endogen terhadap konstruk endogen $(\beta)$ dilakukan dengan metode resampling bootstrap .

Statistik uji yang digunakan adalah statistik $\mathrm{t}$ atau uji t. Nilai $\mathrm{t}$ pembanding dalam penelitian kali ini diperoleh dari tabel t. Nilai t-tabel dengan derajat kebebasan (dk) sebesar 182 dan taraf signifikansi sebesar 5\% diperoleh sebesar 1,96.

Pengujian hipotesis dilakukan dengan melihat output path coefficient dari hasil resampling bootstrap sebagai berikut:

1) Pengaruh Content terhadap User Satisfaction. Hipotesis yang diajukan sebagai berikut :

a) Ho (hipotesis nihil) $: \gamma_{1}=0$; artinya tidak terdapat pengaruh positif Content terhadap User Satisfaction.

b) Нa (hipotesis alternatif) : $\gamma_{1} \neq 0$; artinya terdapat pengaruh positif Content terhadap User Satisfaction.

Output path coefficient dari hubungan konstruk $\mathrm{C}$ dan US sebagai berikut :

Tabel 8. Path Coefficients $\mathrm{C}$ terhadap US

\begin{tabular}{|c|c|c|c|}
\hline Path & $\begin{array}{c}\text { Original } \\
\text { Sample } \\
(\mathbf{O})\end{array}$ & $\begin{array}{c}\text { Sample } \\
\text { Mean } \\
(\mathbf{M})\end{array}$ & $\begin{array}{c}\text { T } \\
\text { Statistics }\end{array}$ \\
\hline C-> US & 0,341297 & $-0,328406$ & 2,331488 \\
\hline
\end{tabular}

Tabel 8 menunjukkan adanya pengaruh positif antara konstruk Content terhadap konstruk User Satisfaction dengan nilai koefisien sebesar 0,34 dan signifikan pada taraf 5\%. Hal ini dibuktikan dari besarnya nilai $\mathrm{t}$ statistik untuk konstruk Content terhadap konstruk User Satisfaction di atas 1,96 yaitu sebesar 2,33. Jadi dapat disimpulkan bahwa Ho ditolak. 
2) Pengaruh Accuracy terhadap User Satisfaction. Hipotesis yang diajukan sebagai berikut :

a) Ho (hipotesis nihil) : $\gamma_{1}=0$; artinya tidak terdapat pengaruh positif Accuracy terhadap User Satisfaction.

b) Ha (hipotesis alternatif) : $\gamma_{1} \neq 0$; artinya terdapat pengaruh positif Accuracy terhadap User Satisfaction.

Output path coefficient dari hubungan

konstruk A dan US sebagai berikut:

Tabel 9. Path Coefficients A terhadap US

\begin{tabular}{|c|c|c|c|}
\hline Path & $\begin{array}{c}\text { Original } \\
\text { Sample } \\
(\mathbf{O})\end{array}$ & $\begin{array}{c}\text { Sample } \\
\text { Mean } \\
(\mathbf{M})\end{array}$ & $\begin{array}{c}\text { T } \\
\text { Statistics }\end{array}$ \\
\hline A -> US & 0,378002 & 0,390233 & 2,113165 \\
\hline
\end{tabular}

Tabel 9 menunjukkan adanya pengaruh positif antara konstruk Accuracy terhadap konstruk User Satisfaction dengan nilai koefisien sebesar 0,37 dan signifikan pada taraf 5\%. Hal ini dibuktikan dari besarnya nilai $\mathrm{t}$ statistik untuk konstruk Accuracy terhadap konstruk User Satisfaction di atas 1,96 yaitu sebesar 2,11. Jadi dapat disimpulkan bahwa Ho ditolak.

3) Pengaruh Format terhadap User

Satisfaction. Hipotesis yang diajukan sebagai berikut :

a) Ho (hipotesis nihil) : $\beta_{1}=0$; artinya tidak terdapat pengaruh positif Format terhadap User Satisfaction.

b) $\mathrm{Ha}$ (hipotesis alternatif) $: \beta_{1} \neq 0$; artinya terdapat pengaruh positif Format terhadap User Satisfaction.

Output path coefficient dari hubungan konstruk F dan US sebagai berikut :
Tabel 10. Path Coefficients F terhadap US

\begin{tabular}{|c|c|c|c|}
\hline Path & $\begin{array}{c}\text { Original } \\
\text { Sample } \\
(\mathbf{O})\end{array}$ & $\begin{array}{c}\text { Sample } \\
\text { Mean } \\
(\mathbf{M})\end{array}$ & $\begin{array}{c}\text { T } \\
\text { Statistics }\end{array}$ \\
\hline F-> US & 0,699281 & 0,666698 & 3,145389 \\
\hline
\end{tabular}

Berdasarkan tabel 13, dapat dilihat bahwa terdapat pengaruh positif antara konstruk Format terhadap konstruk User Satisfaction dengan nilai koefisien sebesar 0,69 dan signifikan pada taraf 5\%. Hal ini dibuktikan dari besarnya nilai $\mathrm{t}$ statistik untuk konstruk Format terhadap kosntruk User Satisfaction di atas 1,96 yaitu sebesar 3,14. Jadi dapat disimpulkan bahwa Ho ditolak.

4) Pengaruh Ease of Use terhadap User Satisfaction. Hipotesis yang diajukan sebagai berikut:

a) Ho (hipotesis nihil) : $\beta_{2}=0$; artinya tidak terdapat pengaruh positif EU terhadap US.

b) Ha (hipotesis alternatif) : $\beta_{2} \neq 0$; artinya terdapat pengaruh positif EU terhadap US.

Output path coefficient dari hubungan konstruk EU dan US sebagai berikut:

Tabel 11. Path Coefficients EU terhadap US

\begin{tabular}{|c|c|c|c|}
\hline Path & $\begin{array}{c}\text { Original } \\
\text { Sample } \\
(\mathbf{O})\end{array}$ & $\begin{array}{c}\text { Sample } \\
\text { Mean } \\
(\mathbf{M})\end{array}$ & $\begin{array}{c}\text { T } \\
\text { Statistics } \\
\mathbf{6}\end{array}$ \\
\hline EU -> US & 0,401100 & $-0,39027$ & 2,449976 \\
\hline
\end{tabular}

Berdasarkan tabel 14, dapat dilihat bahwa terdapat pengaruh positif antara konstruk EU terhadap konstruk US dengan nilai koefisien sebesar 0,40 dan signifikan pada taraf 5\%. Hal ini dibuktikan dari besarnya nilai t statistik untuk konstruk PU terhadap konstruk ACC di atas 1,96 yaitu 
sebesar 2,44. Jadi dapat disimpulkan bahwa Ho ditolak.

5) Pengaruh Timeliness terhadap User Satisfaction. Hipotesis yang diajukan sebagai berikut:

a) Ho (hipotesis nihil) : $\beta_{3}=0$; artinya tidak terdapat pengaruh positif Timeliness terhadap User Satisfaction.

b) Ha (hipotesis alternatif) : $\beta_{3} \neq 0$; artinya terdapat pengaruh positif Timeliness terhadap User Satisfaction.

Output path coefficient dari hubungan konstruk Timeliness terhadap User Satisfaction sebagai berikut :

Tabel 12. Path Coefficients Timeliness terhadap User Satisfaction

\begin{tabular}{|c|c|c||c|}
\hline Path & $\begin{array}{c}\text { Original } \\
\text { Sample } \\
(\mathbf{O})\end{array}$ & $\begin{array}{c}\text { Sample } \\
\text { Mean } \\
(\mathbf{M})\end{array}$ & $\begin{array}{c}\text { T } \\
\text { Statistics }\end{array}$ \\
\hline T->US & 0,282487 & 0,288362 & 2,399131 \\
\hline
\end{tabular}

Berdasarkan tabel 15, dapat dilihat bahwa terdapat pengaruh yang signifikan antara konstruk Timeliness terhadap User Satisfaction. Hal ini dibuktikan dari besarnya nilai t-statistik untuk konstruk Timeliness terhadap User Satisfaction diatas 1,96 yaitu hanya sebesar 2,39 dengan koefisien sebesar 0,28. Jadi dapat disimpulkan bahwa Ho ditolak.

Berdasarkan hasil pengujian hipotesis dapat diketahui bahwa hipotesis yang diterima dalam penelitian ini terdiri dari $\mathrm{H}_{1}$, $\mathrm{H}_{2}, \mathrm{H}_{3}, \mathrm{H}_{4}$, dan $\mathrm{H}_{5}$.

\section{SIMPULAN}

Berdasarkan analisis hasil penelitian dan pembahasan pada bagian sebelumnya, maka dapat ditarik simpulan sebagai berikut: 1) Konstruk Content berpengaruh signifikan terhadap konstruk User Satisfaction. Nilai koefisien variabel latent Content terhadap konstruk User Satisfaction sebesar 0,34 yang berarti terdapat pengaruh positif sebesar 34\%. 2) Konstruk Accuracy berpengaruh signifikan terhadap konstruk User Satisfaction. Nilai koefisien variabel latent Accuracy terhadap konstruk User Satisfaction sebesar 0,37 yang berarti terdapat pengaruh positif sebesar $37 \%$. 3) Konstruk Format berpengaruh signifikan terhadap konstruk User Satisfaction. Nilai koefisien variabel latent Format terhadap konstruk User Satisfaction sebesar 0,69 yang berarti terdapat pengaruh positif sebesar $69 \%$. 4) Konstruk Ease of Use berpengaruh signifikan terhadap konstruk User Satisfaction. Nilai koefisien variabel latent Ease of Use terhadap konstruk User Satisfaction sebesar 0,40 yang berarti terdapat pengaruh positif sebesar $40 \%$. 5) Konstruk Timeliness berpengaruh signifikan terhadap konstruk User Satisfaction. Nilai koefisien variabel latent Timeliness terhadap konstruk User Satisfaction sebesar 0,28 yang berarti terdapat pengaruh positif sebesar $28 \%$.

\section{DAFTAR RUJUKAN}

Aji, S. P., dan Bodroastuti, T., 2013, Penerapan Model Simulasi Antrian Multi Channel Single Phase Pada Antrian Di Apotek Purnama Semarang. Jurnal Kajian Akuntansi Dan Bisnis, 1.

Akadun. 2009. Teknologi Informasi Administrasi. Bandung : Alfabeta.

Bodnar, George H., \& Hopwood, William S. (2012). Accounting information systems. Englewood Cliffs, New Jersey: Prentice Hall.

Djemari Mardapi. (2005). Pengembangan instrumen penelitian pendidikan. Yogyakarta: UNY Press.

Doll, W.J., and Torkzadeh, G, 1988, The Measurement of End User Computing Satisfaction, MIS Quarterly (12:2). 
Doll, W.J., and Torkzadeh, G. (1991) Issues and Opinions - The Measurement of End-User Computing Satisfaction: Theoretical and Methodological Issues, MIS Quarterly, 15, 5-10.Fishbein, M., \& Ajzen, I. (1975). Belief, attitude, intention, and behavior: an introduction to theory and research. Reading, Massachusetts: AddisonWesley.

Imam Ghozali. (2011). Structural equation modeling: Metode alternatif dengan partial least square. Semarang: Badan Penerbit Universitas Diponegoro.

Jogiyanto HM. (2008). Sistem informasi keperilakuan. Yogyakarta: Andi Offset.

Kerlinger, Fred N. (1979). Behavioral research: a conceptual approach. Austin: Holt Rinehart \& Winston.

Lin, L. R. (1988). Educational measurement. New York: Macmillan.

O'Brien, James A. (2005). Introduction to information systems. New York: McGraw-Hill Higher Education.

Suharsimi Arikunto. (2006). Metode Penelitian . Jakarta: Bumi Aksara.

Suharsimi Arikunto. (2010). Prosedur penelitian suatu pendekatan praktek. Jakarta: Penerbit Rineka Cipta.

Wagiran. (2013). Metodologi penelitian pendidikan: teori dan implementasi. Yogyakarta: Deepublish. 